\title{
Environmental impact of COVID-19 pandemic: more negatives than positives
}

\author{
Ankit $^{1} \cdot$ Amit Kumar $^{2} \cdot$ Vartika Jain $^{3} \cdot$ Ankit Deovanshi $^{3} \cdot$ Ayush Lepcha $^{3} \cdot$ Chandan Das $^{3} \cdot$ Kuldeep Bauddh $^{1}$ (D) \\ Sudhakar Srivastava ${ }^{3}$
}

Received: 31 July 2020 / Revised: 22 December 2020 / Accepted: 13 January 2021 / Published online: 20 February 2021

(c) Society for Environmental Sustainability 2021

\begin{abstract}
Coronaviruses are the well-known cause of severe respiratory, enteric and systemic infections in a wide range of animal hosts including man. The scientific interest on coronaviruses has increased since the outbreak of COVID-19 (SARS-CoV-2) that initiated in Wuhan, China. This was soon declared a 'Public Health Emergency of International Concern' by World Health Organisation (WHO). Presently, the best strategy against this pandemic is prevention through regular hand and face washes, use of masks, gloves and personal protective equipment and social distancing. At the government level, the task is to perform as many tests as possible to identify coronavirus infected people and to isolate them to avoid the uncontrollable spread of the virus. The ongoing and future strategies against coronavirus ensue that huge quantity of masks, plastic products (personal protective equipment (PPE) kits, face shields, etc.) and chemicals (chloroxylenol, chlorine, $\mathrm{H}_{2} \mathrm{O}_{2}$, etc.) would be generated as waste in near future. Further, the amount of water consumption per person shall also increase. These effects can have unforeseen impacts on the environment. Apart from this, the ecological impacts on human-animal interactions can also be seen, such as people avoiding pets in coming future as a health and safety measure. The present review gives an overview of coronavirus, its current state of spread and environmental and ecological risks ensuing from the pandemic.
\end{abstract}

Keywords COVID-19 $\cdot$ Environment $\cdot$ Plastic $\cdot$ Pollution $\cdot$ Sanitizer

\section{Introduction}

Coronavirus has become the hottest word and the most debated topic in the world due to the magnitude of infections and the number of deaths it has caused. In late December, 2019, a case of unidentified pneumonia was reported in Wuhan, Hubei Province, People's Republic of China (PRC).

Ankit and Amit Kumar contributed equally to this work.

Kuldeep Bauddh

kuldeep.bauddh@cuj.ac.in

Sudhakar Srivastava

sudhakar.srivastava@gmail.com

1 Department of Environmental Sciences, Central University of Jharkhand, Ranchi, India

2 Department of Botany, Lucknow University, Lucknow 226007, India

3 Plant Stress Biology Laboratory, Institute of Environment and Sustainable Development, Banaras Hindu University, Varanasi 221005, India
The identified clinical features were similar to that of viral pneumonia (Chan et al. 2020; Holshue et al. 2020). The experts of PRC Center for Disease Control, after analyzing the respiratory samples, declared that the pneumonia was caused by a novel coronavirus, later known as Novel Coronavirus Pneumonia (NCP). World Health Organization (WHO) officially named the coronavirus disease as 'COVID-19'. While the International Committee on Taxonomy of Viruses named the virus 'severe acute respiratory syndrome coronavirus 2' (SARS-CoV-2). SARS-CoV-2 is a member of the family Coronaviridae and order Nidovirales. The family consists of two subfamilies, Coronavirinae and Torovirinae and members of the subfamily Coronavirinaeare subdivided into four genera, namely Alphacoronavirus, Betacoronavirus, Gammacoronavirus and Deltacoronavirus (Burrell et al. 2016). SARS-CoV-2 is a $\beta$-coronavirus, enveloped and non-segmented positive-sense RNA virus (Zhu et al. 2020). It was found to be closely related to two bat-derived severe acute respiratory syndrome (SARS)-like coronaviruses, bat-SL-CoVZC45 and bat-SL-CoVZXC21, reported from Eastern parts of China (Lu et al. 2020). A 
study analyzed genome sequences of SARS-CoV-2, RaTG13 (a bat coronavirus previously detected in Rhinolophus affinis from Yunnan Province, China), and SARS-CoV (Zhou et al. 2020). It found that the SARS-CoV-2 virus is more related to BatCoV RaTG13, (Zhou et al. 2020). However, a few other studies suggested the virus to have originated from ant eaters/pangolins (Guan-Zhu 2020). Therefore, the origin of the SARS-CoV-2 still remains controversial and needs more analyses for confirmatory results.

COVID-19 spread to almost all the countries of the world in virtually no time (Ali and Alharbi, 2020). Within a short span of time, it led to more than 36.0 million confirmed cases in 216 countries. There were 37,423,660 confirmed cases worldwide with an agonizing 1,074,817 deaths according to the World Health Organization (WHO) on 12th October, 2020 (Fig. 1). The most common routes of SARS-CoV-2 transmission are droplets, close-contact with the infected person and also by the aerosol transmission (Xiao et al. 2020). SARS-CoV-2 infection has been most frequently observed in adult male patients between the ages 34-59 years (Jing et al. 2020). The most common symptoms of COVID-19 include fever, dry cough, tiredness (Tian et al. 2020) whereas, some other observed symptoms are diarrhea, pain, sore throat, headache, gustatory dysfunction, skin rashes and discoloration on fingers or toes (COVIDToe; painful purple or red lesion on toes of the patient). The severe symptoms include dyspnea, pain in the chest, and loss of movement or speech (WHO 2020; Guo et al. 2020; Qin et al. 2020). According to Banerjee et al. (2020), the fatality outcome of strains depends on three important factors; (a) uniqueness of variations in alleles, (b) the number of mutations present, (c) and the overall functional outcome of mutation at the protein level. The surface glycoprotein domain is important domain for host-carrier interaction with viruses. Therefore, the mutation related to surface glycoprotein can alter the virus entry and pathogenesis. Also, there are chances of host genetic factors which can modulate the evolution of viral genome (Banu et al. 2020). People of all ages, including young newborn babies, can become infected (Schwartz 2020; Cruz and Zeichner 2020). Most of the people (about $80 \%$ ) got recovered from the disease without taking treatment from the hospital. However, aged people, and those with some medical problems, especially high blood pressure, heart and lung problems, diabetes, or cancer, are at high risk of developing serious illness (Jing et al. 2020). In severe cases, COVID-19 can be complicated by acute respiratory distress syndrome (ARDS), sepsis and septic shock, multi-organ failure, including acute kidney and cardiac injury (Yang et al. 2020).

Apart from these core symptoms, the disease is resulting in stress, tension, fights, sleep disorders and other addictions. Self-confinement and solitary lifestyle are severely affecting physical and mental wellbeing (Rajkumar 2020). COVID-19 also has social and economic impacts. It has affected almost all the sections of society, but, the poor people have been the most affected, particularly due to coronavirus-induced lockdown measures (Singh 2020; Chakraborty and Maity 2020; Bashir et al. 2020).

The lockdown imposed throughout the world has inflicted serious dents into the economy and crippled the nations on several fronts (Gopalan and Misra 2020). The economy has witnessed shock at both demand and supply fronts. The cost of lockdown per week has been estimated to be $\$ 26$ billion, which is much higher than estimated $\$ 16.6$ billion (Live mint 2020). The world economy is expected to shrink by $3.9 \%$ in 2020 . Therefore, several countries have announced
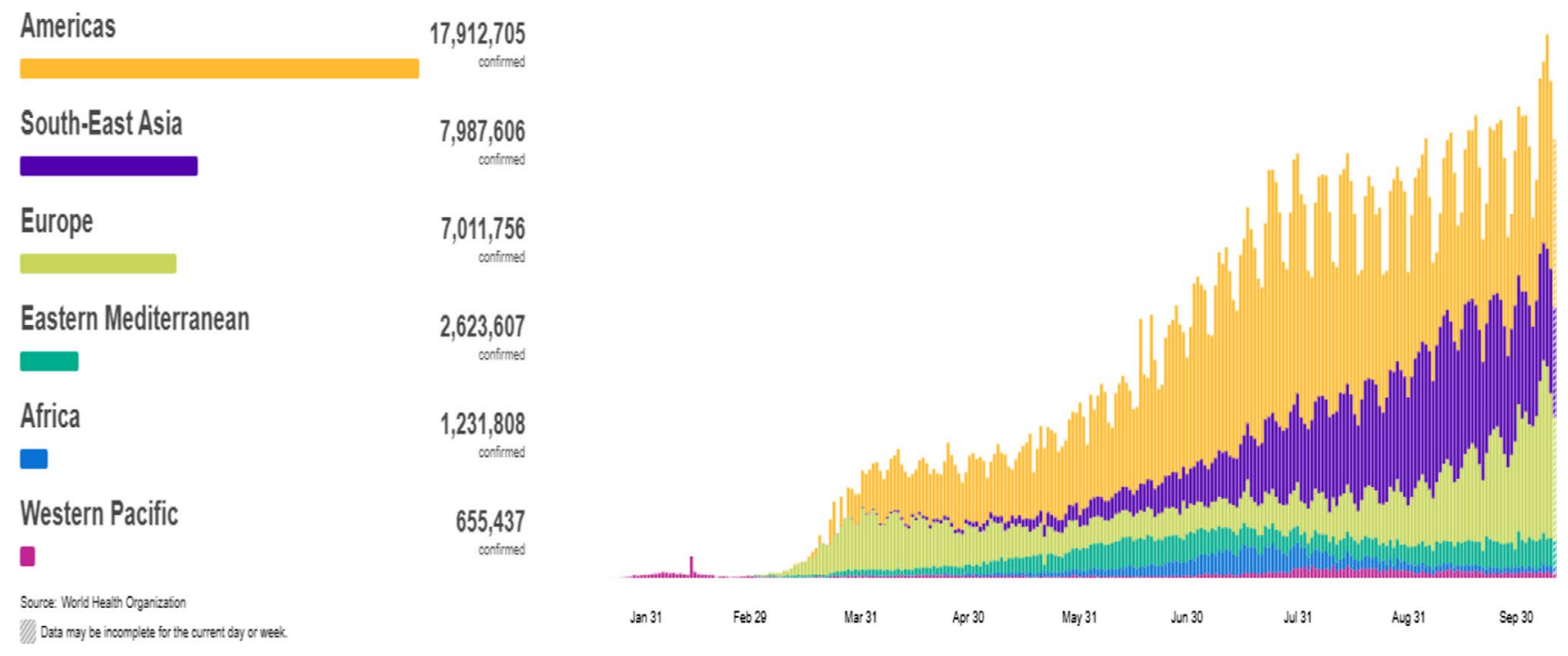

Fig. 1 Total number of infected persons throughout the world on 12/10/2020 (WHO 2020) 
huge packages to support economic fallout (Economic Times 2020; Pha and Narayan 2020; Saadat et al. 2020).

COVID-19 has also impacted the environment severely and indirectly. The usage of pesticides, soaps, detergents, single-use plastic etc. has increased many-fold in the past few months and is taking a heavy toll on the environment (Pata 2020; Zambrano-Monserrate et al. 2020; Saadat et al. 2020). Sanitization of roads, complexes and whole cities has been carried out in the past few months. The use of hand sanitizers has also increased manifold (Mahmood et al. 2020). Personal protective equipment (PPE) kits, face masks, and gloves have emerged as critical safety measures during the ongoing pandemic (Herron et al. 2020a, b; Shakil et al. 2020; Rowan and Laffey 2020). Due to an abrupt increase in their use, the environment may face negative consequences of increased contamination in the near future. Reports from China indicate that a large number of clinical trashes are being generated, which is approximately four times more than the normal days (Saadat et al. 2020). In the present review, the environmental and ecological consequences of COVID-19 have been discussed.

\section{Environmental perspectives of COVID-19}

The novel Coronavirus has caused unprecedented impacts throughout the world at medical, social, economic and environmental levels. It seems like the world has been put into a reset mode. The shutdown of industrial facilities, power plants, decreased transportation and shipping resulted in decreased levels of criteria pollutants such as carbon monoxide $(\mathrm{CO})$, nitrogen oxide $\left(\mathrm{NO}_{2}\right)$, methane $\left(\mathrm{CH}_{4}\right)$, sulfur oxide $\left(\mathrm{SO}_{2}\right)$, black carbon (BC) and particulate matter $\left(\mathrm{PM}_{10}\right.$ and $\mathrm{PM}_{2.5}$ ) (Srivastava et al. 2020; Gautam 2020; He et al. 2020; Saadat et al. 2020; Zambrano-Monserrate et al. 2020; Tobías et al. 2020). Due to a reduction in commercial activities and public transportation, noise pollution was also reduced (Zambrano-Monserrate et al. 2020). Muhammad et al.
(2020) found that the lockdown resulted in a 30\% decrease in air pollution (China, France, Europe, Italy, Spain and USA) while mobility was curbed by approximately $90 \%$. However, these positive effects were due to the imposed lockdown in several countries particularly during the initial phase of coronavirus and these positive impacts were only short-term benefits. As various activities resume to normal levels, these positive environmental effects have started to vanish.

On the other hand, coronavirus pandemic has some negative impacts that may continue for long periods in the future (Fig. 2).

Mass disinfection and worldwide usage of hand sanitizers containing alcohol and isopropanol are on the rise (Mahmood et al. 2020). Disinfectants like sodium hypochlorite, hypochlorous acids and chlorine are used in large quantities in almost all places where there are human habitations. They are rapidly degraded in the presence of organic matter and therefore, do not bioaccumulate and persist in the environment. Sodium hypochlorite is used for mopping of floors, lobbies, elevators, corridors, offices, rooms, hospitals etc. for killing the virus (Geller et al. 2012). Sodium hypochlorite is very toxic to the environment and microorganisms. However, as the substance is extremely reactive, sodium hypochlorite or its related chemicals poured into the drain from household uses might react with organic matter and can get removed before reaching the environment. Other alcohol-based solutions like isopropanol/ethanol also significantly remove the virus (Rabenau et al. 2005). Antibacterial soaps contain triclocarban and triclosan. Triclosan is a health hazard and is known to give rise to antibiotic-resistant strains of bacteria (Yueh and Tukey 2016). These chemicals are responsible for causing endocrine disruption, liver cancer and have several other neurological effects (Gee et al. 2008). Both chemicals are detrimental to the health of the environment as they are difficult to degrade and they form $60 \%$ of the mass of all drugs that are found in the sludge of waste water treatment plant and sewage. These chemical contaminants have an adverse impact on aquatic fauna (Chalew and Halden 2009).
Fig. 2 A summary of positive and negative effects of COVID19 on the environment

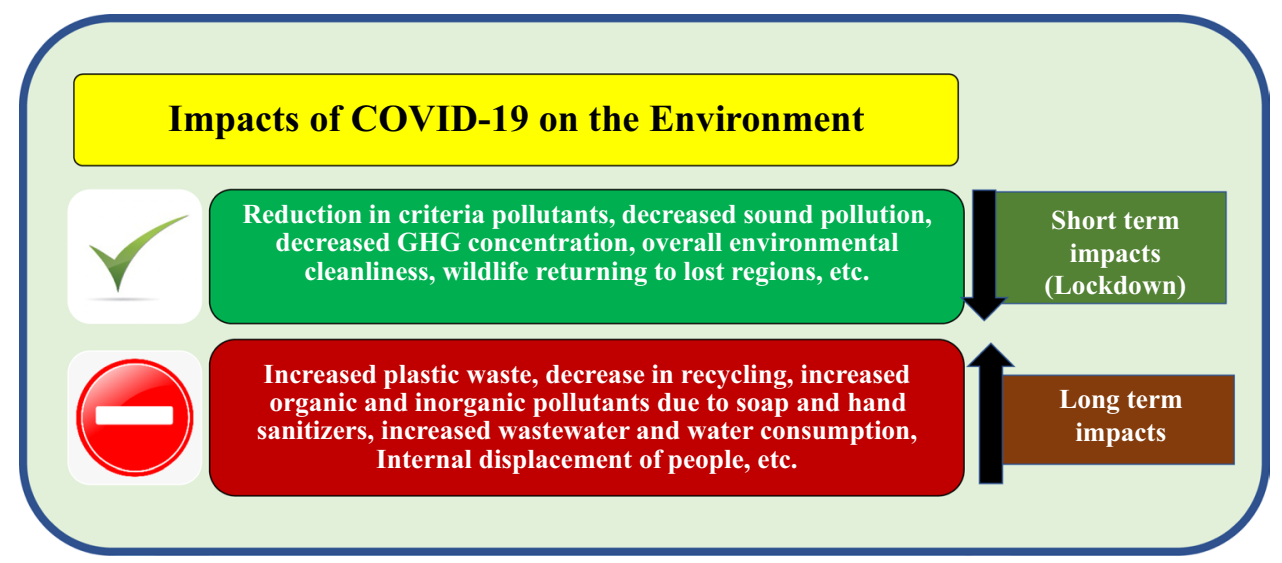




\section{Pollution due to plastic materials, gloves, gowns and other PPEs and biomedical waste}

Single-use masks, wipes, bottles of sanitizers and gloves are critical for the safety of the frontline workers of Corona pandemic (Herron et al. 2020a, b; Shakil et al. 2020; Rowan and Laffey 2020). Amidst increasing fear, single-use plastic manufacturing industries are trying to seize the opportunity and make a comeback into their otherwise declining business. This would definitely lead to an abrupt surge in the use of plastics. Many grocery stores are not allowing customers to bring their reusable bags and are instead delivering products in single use plastic bags. In restaurants there is an increase in the frequency of online ordering of food which resulted in a per capita increase in plastic usage (Klemes et al. 2020). Silva et al. (2020) showed that worldwide plastic pollution increased due to COVID-19 pandemic. Plastic demand in terms of packaging (40\%) and other applications (17\%) including medical uses has significantly increased (Prata et al. 2020).

The safe disposal of plastics after use has become a matter of grave concern. It has come as a blow to our collective fight against plastic pollution. The products are ending up in places where they must not be. They can easily be found on streets, in wild habitats and in the seas (DW 2020). Masks are scattered across roads, sidewalks and parks as people are striving hard to protect themselves from the virus. If the masks reach the oceans, they can pose a serious threat to marine life. The safe disposal of PPEs is also matter of concern (Klemes et al. 2020; Vanapalli et al. 2020). It is important to note that SARS-CoV-2 is more stable on plastic and stainless steel than on copper and cardboard, and the viable virus particles can be detected up to $72 \mathrm{~h}$ after application to these surfaces (Doremalen et al. 2020). Although, gloves made of latex rubber are natural products but there are apprehensions of them being not always eco-friendly. Chemicals used in their manufacturing are not environmentally safe and the disposal of such wastewater is another problem (Kumar et al. 2020).

\section{Management of bio-medical waste during COVID-19}

The biomedical waste (BMW) generation from COVID-19 patients is increasing throughout the world. India is producing approximately 550 tons of biomedical waste (BMW) per annum which are treated by only 198 Common Bio-Medical Waste Treatment Facilities (CBMWTFs) and 225 captive incinerators (Singh et al. 2019; Yadav et al. 2020). It has been reported that during the present epidemic in Wuhan, China, the city produced 240 tons of additional medical waste per day (Ranjan et al. 2020; Yu et al. 2020; ZambranoMonserrate et al. 2020).
There is a concern about the management of COVID19 waste; as the cases increase, the treatment centers are becoming overburdened by such medical waste, and if precautions are not ensured, it could result in infections among sanitary workers. There lies risk of mixing of COVID-19 waste with regular medical waste including food waste from COVID-19 wards. Regular sanitization of workers and adequate personal protective equipment including three-layer masks, splash-proof aprons/gowns, nitrile gloves, gumboots, and safety goggles involved in handling and collection of biomedical waste should be mandatory. However, this is going to lead to huge increase in the generation of BMW.

Dedicated vehicles must be employed to collect COVID19 ward waste and its sanitization. The proper monitoring is quite essential while disposing of COVID-19 waste so the workers should not get infected by it (Kumar et al. 2020; Ranjan et al. 2020; Mahmood et al. 2020). For discarding the BMW properly, it is important to know the composition so that its proper disposal can be ensured (Ilyas et al. 2020). Some of the promising ways to get rid of BMW is incineration at high temperatures between 800 and $1200{ }^{\circ} \mathrm{C}$, which kills the pathogens and also reduces organic matter by up to $90 \%$ (Wang et al. 2020). High temperature pyrolysis and medium temperature microwave technique are two primary alternative thermal technologies that are available to deal with biomedical waste (Ilyas et al. 2020). Chemical disinfection may also be used to pre-treat COVID-19 waste before mechanical shredding.

\section{Impact on soil and water ecosystems}

The components of the ecosystem are intertwined with each other. With every person washing hands more regularly with soap, mass disinfection by government and local bodies, and production of single-use plastics containing bisphenol A (BPA) are destined to have negative impacts on soil and water quality (Atolani et al. 2020). Alcohol containing products spilled in the water are toxic to aquatic fauna and spill in soil may also pollute the groundwater (Mahmood et al. 2020). Soaps are the oldest known detergents. Discharged detergents cause foam in water bodies. Foam is produced due to lowered surface tension of water by soaps and other detergents (Bowers 1952). Soaps can reduce re-aeration by 40\% (Gameson and Barrett 1958). These substances form a protective surface film which acts as an obstacle at the airwater interface (Baars 1995). According to Van Beneden (1952), $120 \mathrm{mg} / \mathrm{l}$ of soap can prevent the growth and development of algae. Aquatic plants can be adversely affected by soaps. Species like Ranunculus aquatilis, Potamogeton cannot grow in $2.5 \mathrm{ppm}$ of detergent. Accumulation of harmful pollutants in soil as a result of extensive use of soaps may deteriorate the quality of the soil (Taylor 1980; Atolani et al. 2020). 
The acute increase in soapy discharge over a short period of time from every household may increase the amount of pollutants and alter the chemistry of grey-water. Such domestic effluent will pollute the river water, and ultimately, the lakes and oceans. This unwelcoming chain of events is going to be a serious issue in the near future. It must be noted that this discharge is over and above the normal everyday discharge which was already occuring (Fig. 3).

\section{Ecological perspectives of COVID 19}

Amidst corona pandemic, particularly during the lockdown phase, some positive effects were observed on the to the wildlife. During lockdown phase, animals had an increased and uninterrupted territory. In some areas, wild animals were seen on roads and residential areas. Less traffic, less human intervention, and less pollution gave space to wildlife to thrive. It was definitely a rare phenomenon on the roads. Wildlife re-entered to the areas snatched from them. Dolphins came to the tourist waterfront; birds were heard and seen like never before in the urban centers. During the lockdown, the wildlife was at peace with less flow of humans and tourists (Rutz et al. 2020; Nabi et al. 2020). However with increased mobility, these animals became vulnerable to poaching. A significant increase in overall poaching of wild animals in some areas was observed during the lockdown period; especially in the areas which were not protected or not marked to any specific wildlife area. If left unregulated, the poaching of ungulates and small animals may lead to a depletion of the prey base for predators. This might, in turn, result in increase in human-animal conflicts (Badola 2020; Gordo et al. 2020; Manenti et al. 2020). However, these positive and negative impacts were transient and were largely observed during the complete lockdown phase only.

The ripples of corona effect are far-reaching. Along with humans, animals residing in urban areas, as well as the wild ones, are getting infected. The list includes dogs, cats, rabbits, mink and even tigers and lions. It is indicative of the fact that coronavirus can transfer from human to animals (Shi et al. 2020). With the news of the presence of coronavirus more than 5,00,000 minks have been killed by suffocation in the Netherlands (National Geographic 2020). Further, stray animals like dogs and cats are amongst the sufferers of coronavirus pandemic owing to the absence of waste food material due to restaurants and shops being closed since the inception of lockdown; particularly in the developing countries like India. Also, they are being abandoned by their owners due to unfounded fears that they may spread COVID19 . The worst possibility is that the stray animals might eat disposed masks and gloves, which can become lethal.

\section{Conclusions and future perspectives}

Although a few positive impacts of COVID-19 on the environment were seen, these were the short-term effects induced largely by nation-wide lockdown. Indeed, the pandemic is expected to pose long-term adverse effects on the environment in future. The use of chemicals (soaps, detergents and

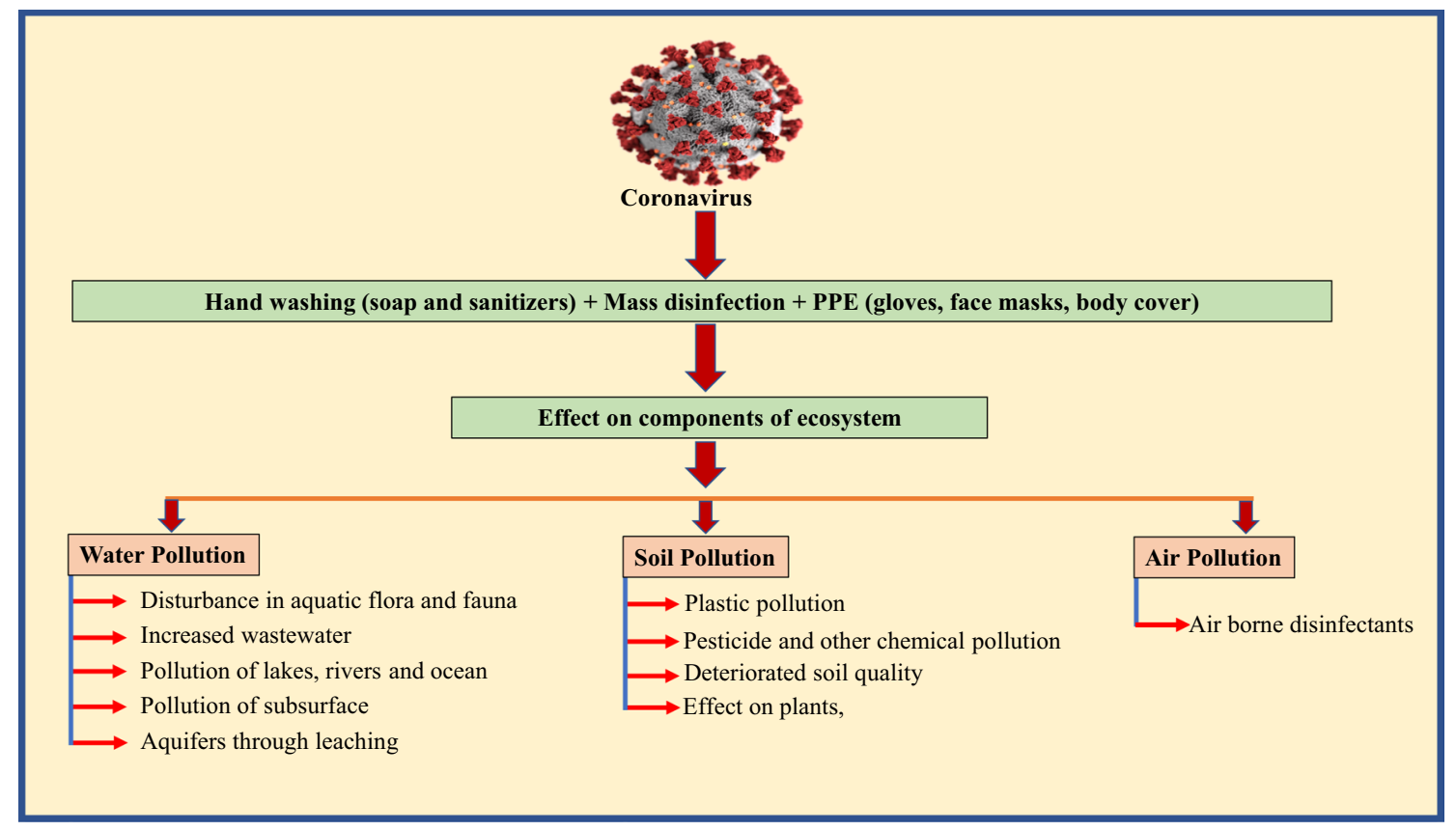

Fig. 3 Cascade effect of Corona virus on different components of ecosystem 
other chemical means of cleaning), medicines, and plastics (gloves, masks, PPE kits, syringes, etc.) is expected to enhance further leading to increased environmental pollution. To tackle the ongoing and future impacts of COVID19 , the need is:

(i) To frame policy guidelines and implement them at international and national levels for proper management of plastic and chemical waste and wastewater treatment.

(ii) To develop safety guidelines and ensure their implementation for doctors, sanitary workers, and hospital staff so as to keep them healthy and to also avoid any viral spread.

(iii) To drive awareness programs and campaigns at various levels including schools, colleges, villages etc. to avoid spread of wrong information and misconceptions and to guarantee proper implementation of various guidelines.

(iv) To understand environmental and ecological impacts of COVID-19 with concerted research efforts so that in future such adversities may be tackled in a more effective way.

(v) To develop database of elderly people who might require more care, proper and timely treatment due to COVID-19 and to ensure their health and care in future

(vi) To also understand the mental stress and psychology of children who had been forced to live in locked conditions in homes and to develop environment and safe conditions for their outing, games and sports activities.

Acknowledgements Kuldeep Bauddh acknowledges DST-Science and Engineering Research Board (SERB), New Delhi, India for financial support (EEQ/2017/000476). The authors are thankful to Department of Botany, University of Lucknow. Amit Kumar is thankful to SERB, DST, New Delhi for the award and financial assistance in form of SERB-NPDF.

\section{References}

Ali I, Alharbi OM (2020) COVID-19: disease, management, treatment, and social impact. Sci Total Environ 728:138861. https:// doi.org/10.1016/j.scitotenv.2020.138861

Atolani O, Baker MT, Adeyemi OS, Olanrewaju IR, Hamid AA, Ameen OM, Oguntoye SO, Usman LA (2020) COVID-19: Critical discussion on the applications and implications of chemicals in sanitizers and disinfectants. EXCLI J 19:785

Baars JK (1955) The effect of detergents on aeration: a photographic approach to the problem. JPISP (Pt. 4) 358-362

Badola S (2020) Indian wildlife amidst the COVID-19 crisis: an analysis of status of poaching and illegal wildlife trade. TRAFFIC, India oce
Banerjee S, Dhar S, Bhattacharjee S, Bhattacharjee P (2020) Decoding the lethal effect of SARS-CoV-2 (novel coronavirus) strains from global perspective: molecular pathogenesis and evolutionary divergence. BioRxiv. doi:https://doi. org/10.1101/2020.04.06.027854

Banu S, Jolly B, Mukherjee P, Singh P, Khan S, Zaveri L et al (2020) A distinct phylogenetic clade of Indian SARS-CoV-2 isolates. BioRxiv. https://doi.org/10.1101/2020.05.31.126136

Bashir MF, Benjiang MA, Shahzad L (2020) A brief review of socioeconomic and environmental impact of Covid-19. Air Qual Atmos Health 13:1403-1409. https://doi.org/10.1007/s11869-020-00894 $-8$

Bowers DR (1952) Measurement of surface tension of sewage, II. Indianapolis studies. Sew Ind Wastes 24:1447-1455

Burrell C, Howard C, Murphy F, Fenner W (2016) Medical virology, 5th edn. Academic Press, New York. https://doi.org/10.1016/ B978-0-12-375156-0.00031-X

Chakraborty I, Maity P (2020) COVID-19 outbreak: migration, effects on society, global environment and prevention. Sci Total Environ 728:138882. https://doi.org/10.1016/j.scitotenv.2020.138882

Chalew TE, Halden RU (2009) Environmental exposure of aquatic and terrestrial biota to triclosan and triclocarban. J Am Water Resour Assoc 45(1):4-13. doi:https://doi.org/10.111 1/j.1752-1688.2008.00284.x

Chan JFW, Kok KH, Zhu Z, Chu H, To KKW, Yuan S, Yuen KY (2020) Genomic characterization of the 2019 novel human-pathogenic coronavirus isolated from a patient with atypical pneumonia after visiting Wuhan. Emerg Microbes Infect 9(1):221-236. doi:https://doi.org/10.1080/22221751.2020.1719902

Cruz AT, Zeichner SL (2020) COVID-19 in children: initial characterization of the pediatric disease. Pediatrics. https://doi.org/10.1542/ peds.2020-0834

Doremalen NV, Bushmaker T, Morris DH, Holbrook MG, Gamble A, Williamson BN, Tamin A, Harcourt JL, Thornburg NJ, Gerber SI, Lloyd-Smith JO, de Wit E, Munster VJ (2020) Aerosol and surface stability of SARS-CoV-2 as compared with SARSCoV-1. N Engl J Med 382:1564-1567

DW (Deutsche Welle), Germany (2020) https://www.dw.com/en/coron avirus-plastic-waste-polluting-the-environment/a-53216807. Accessed 23 April 2020

Economics Times (2020) https://economictimes.indiatimes.com/marke ts/coronavirus-impact-on-economy. Accessed 15 June 2020

Gameson ALH, Barrett MJ (1958) Oxidation, reaeration, and mixing in the Thames estuary. Oxyg Relationsh Streams (US Department of Commerce, NTIS PB-214) 898:63-93

Gautam S (2020) The influence of COVID-19 on air quality in India: a boon or inutile. Bull Environ Contam Toxicol 104:724-726. https ://doi.org/10.1016/j.envpol.2020.114466

Gee RH, Charles A, Taylor N, Darbre PD (2008) Oestrogenic and androgenic activity of triclosan in breast cancer cells. J Appl Toxicol Int J 28(1):78-91. https://doi.org/10.1002/jat.1316

Geller C, Varbanov M, Duval RE (2012) Human coronaviruses: insights into environmental resistance and its influence on the development of new antiseptic strategies. Viruses 4(11):30443068. doi:https://doi.org/10.3390/v4113044

Gopalan HS, Misra A (2020) COVID-19 pandemic and challenges for socio-economic issues, healthcare and National Health Programs in India. Diabetes Metab Syndr 14:757-759

Gordo O, Brotons L, Herrando S, Gargallo G (2020) Rapid behavioral response of urban birds to COVID-19 lockdown. bioRxiv. https ://doi.org/10.1101/2020.09.25.313148

Guan-Zhu H (2020) Pangolins harbor SARS-CoV-2-related Coronaviruses. Trends Microbiol. https://doi.org/10.1016/j. tim.2020.04.001

Guo W, Li M, Dong Y, Zhou H, Zhang Z, Tian C, Qin R, Wang H, Shen Y, Du K, Zhao L (2020) Diabetes is a risk factor for the 
progression and prognosis of COVID19. Diabetes Metab Res Rev. https://doi.org/10.1002/dmrr.3319

He G, Pan Y, Tanaka T (2020) COVID-19, city lockdown, and air pollution: evidence from China. medRxiv. https://doi. org/10.1101/2020.03.29.20046649

Herron JBT, Hay-David AGC, Gilliam AD, Brennan PA (2020a) Personal protective equipment and COVID 19: a risk to healthcare staff? Br J Oral Maxillfac Surg 58(5):500-502

Herron JBT, Hay-David AGC, Gilliam AD, Brennan PA (2020b) Personal protective equipment and COVID 19-a risk to healthcare staff? Br J Oral Maxillfac Surg 58(5):500-502

Ilyas S, Srivastava RR, Kim H (2020) Disinfection technology and strategies for COVID-19 hospital and bio-medical waste management. Sci Total Environ 749:141652. https://doi. org/10.1016/j.scitotenv.2020.141652

Jing YY, Zheng X, Gou K, Pu Z, Chen Q, Guo R, Ji H, Wang Y, Wang Y, Zhou (2020) Prevalence of comorbidities and its effects in patients infected with SARS-CoV-2: a systematic review and meta-analysis. Int J Infect Dis 94:91-95. https:// doi.org/10.1016/j.ijid.2020.03.017

Klemes JJ, Fan YV, Tan RR, Jiang P (2020) Minimizing the present and future plastic waste, energy and environmental footprints related to COVID-19. Renew Sust Energ Rev 127:109883. https ://doi.org/10.1016/j.rser.2020.109883

Kumar V, Singh SB, Singh S (2020) COVID-19: environmental concern and impact of Indian medicinal system. J Environ Chem Eng 8(5):104144. https://doi.org/10.1016/j.jece.2020.104144

Live mint (2020) https://www.livemint.com/market/mark-to-market/ what-is-the-economic-cost-of-an-extended-covid-19-lockdown11586852662704.html. Accessed 15 June 2020

Lu R, Zhao X, Li J, Niu P, Yang B, Wu H, Wang W, Song H, Huang B, Zhu N, Bi Y (2020) Genomic characterisation and epidemiology of 2019 novel coronavirus: implications for virus origins and receptor binding. Lancet 395(10224):565-574. https://doi. org/10.1016/S0140-6736(20)30251-8

Mahmood A, Eqan M, Pervez S, Alghamdi HA, Tabinda AB, Yasar A, Brindhadevi K, Pugazhendhi A (2020) COVID-19 and frequent use of hand sanitizers; human health and environmental hazards by exposure pathways. Sci Total Environ 742:140561. https://doi.org/10.1016/j.scitotenv.2020.140561

Manenti R, Mori E, Di Canio V, Mercurio S, Picone M, Caffi M, Brambilla M, Ficetola GF, Rubolini D (2020) The good, the bad and the ugly of COVID-19 lockdown effects on wildlife conservation: Insights from the first European locked down country. Biol Conserv 249:108728

Muhammad S, Long X, Salman M (2020) COVID-19 pandemic and environmental pollution: a blessing in disguise? Sci Total Environ. https://doi.org/10.1016/j.scitotenv.2020.138820

Nabi G, Wang Y, Hao Y, Khan S, Wu Y, Li D (2020) Massive use of disinfectants against COVID-19 poses potential risks to urban wildlife. Environ Res 188:109916

National Geographic (2020) https://www.nationalgeographic.com/ animals/2020/06/covid19-forces-mink-farm-end-netherland s/.\&nbsp;Accessed 25 June 2020

Pata UK (2020) How is COVID-19 affecting environmental pollution in US cities? Evidence from asymmetric Fourier causality test. Air Qual Atmos Health 13(10):1149-1155

Pha DHB, Narayan PK (2020) Country responses and the reaction of the stock market to COVID-19-a preliminary exposition. Emerg Mark Finance Trade 56(10):2138-2150

Prata JC, Silva AL, Walker TR, Duarte AC, Rocha-Santos T (2020) COVID-19 pandemic repercussions on the use and management of plastics. Environ Sci Technol 54(13):7760-7765

Qin C, Zhou L, Hu Z, Zhang S, Yang S, Tao Y, Xie C, Ma K, Shang K, Wang W, Tian DS (2020) Dysregulation of immune response in patients with COVID-19 in Wuhan, China. Clin Infect Dis. https://doi.org/10.1093/cid/ciaa248

Rabenau HF, Cinatl J, Morgenstern B, Bauer G, Preiser W, Doerr HW (2005) Stability and inactivation of SARS coronavirus. Med Microbiol Immunol 194(1):1-6. DOI:https://doi.org/10.1007/ s00430-004-0219-0

Rajkumar RP (2020) COVID-19 and mental health: a review of the existing literature. Asian J Psychiatr 52:102066

Ranjan MR, Tripathi A, Sharma G (2020) Medical waste generation during COVID-19 (SARS-CoV-2) pandemic and its management: an Indian perspective. Asian J Environ Ecol. https://doi. org/10.9734/ajee/2020/v13i130171

Rowan NJ, Laffey JG (2020) Unlocking the surge in demand for personal and protective equipment (PPE) and improvised face coverings arising from coronavirus disease (COVID-19) pandemic: implications for efficacy, re-use and sustainable waste management. Sci Total Environ 752:142259. https://doi.org/10.1016/j. scitotenv.2020.142259

Rutz C, Loretto MC, Bates AE, Davidson SC, Duarte CM, Jetz W, Johnson M, Kato A, Kays R, Mueller T, Primack RB (2020) COVID-19 lockdown allows researchers to quantify the effects of human activity on wildlife. Nat Ecol Evol 4(9):1156-1159

Saadat S, Rawtani D, Hussain CM (2020) Environmental perspective of COVID-19. Sci Total Environ. https://doi.org/10.1016/j.scito tenv.2020.138870

Schwartz DA (2020) An analysis of 38 pregnant women with COVID19 , their newborn infants, and maternal-fetal transmission of SARS-CoV-2: maternal coronavirus infections and pregnancy outcomes. Arch Pathol Lab Med. https://doi.org/10.5858/ arpa.2020-0901-SA

Shakil MH, Munim ZH, Tasnia M, Sarowar S (2020) COVID-19 and the environment: a critical review and research agenda. Sci Total Environ 745:141022. https://doi.org/10.1016/j.scito tenv.2020.141022

Shi J, Wen Z, Zhong G, Yang H, Wang C, Huang B, Liu R, He X, Shuai L, Sun Z, Zhao Y (2020) Susceptibility of ferrets, cats, dogs, and other domesticated animals to SARS-coronavirus 2. Science 368(6494):1016-1020. https://doi.org/10.1126/science.abb7015

Silva ALP, Prata JC, Walker TR, Duarte AC, Ouyang W, Barcelò D, Rocha-Santos T (2020) Increased plastic pollution due to COVID19 pandemic: challenges and recommendations. Chem Eng J 405:126683. https://doi.org/10.1016/j.cej.2020.126683

Singh K (2020) How to Manage the Economic Fallout of the Coronavirus. Briefing Paper \# 33, March 19, 2020. Change. https:// www.chathamhouse.org/2020/03/how-fight-economic-falloutcoronavirus

Singh A, Unnikrishnan S, Dongre S (2019) Biomedical waste management in India: awareness and novel approaches. Biomed J Sci Tech Res. https://doi.org/10.26717/BJSTR.2019.13.002424

Srivastava S, Kumar A, Bauddh K, Gautam AS, Kumar S (2020) 21-Day lockdown in India dramatically reduced air pollution indices in Lucknow and New Delhi. Bull Environ Contam Toxicol, India. https://doi.org/10.1007/s00128-020-02895-w

Taylor A (1980) Soaps and detergents and the environment. J Am Oil Chem Soc 57(11):A859-A861

Tian S, Hu N, Lou J, Chen K, Kang X, Xiang Z, Chen G (2020) Characteristics of COVID-19 infection in Beijing. J Infect. 80(4):401406. https://doi.org/10.1016/j.jinf.2020.02.018

Tobías A, Carnerero C, Reche C, Massagué J, Via M, Minguillón MC, Alastuey A, Querol X (2020) Changes in air quality during the lockdown in Barcelona (Spain) one month into the SARSCoV-2 epidemic. Sci Total Environ 726:138540. https://doi. org/10.1016/j.scitotenv.2020.138540

Van Beneden G (1952) Biological aspects of the problem of detergents in domestic sewage. Bull Cebedeau 17:159-164. DOI:https://doi. org/10.5772/61250 
Vanapalli KR, Sharma HB, Ranjan VP, Samal B, Bhattacharya J, Dubey BK, Goel S (2020) Challenges and strategies for effective plastic waste management during and post COVID-19 pandemic. Sci Total Environ 750:141514. https://doi.org/10.1016/j.resco nrec.2020.105052

Wang J, Shen J, Ye D, Yan X, Zhang Y, Yang W, Li X, Wang J, Zhang L, Pan L (2020) Disinfection technology of hospital wastes and wastewater: suggestions for disinfection strategy during coronavirus disease 2019 (COVID-19) pandemic in China. Environ Pollut 262:Article 114665. https://doi.org/10.1016/j.envpol.2020.114665

World Health Organization (WHO) (2020) Coronavirus disease (COVID-2019) situation reports, Geneva. https://www.who.int/ emergencies/diseases/novel-coronavirus-2019. Accessed 25 June 2020

Xiao F, Tang M, Zheng X, Liu Y, Li X, Shan H (2020) iEvidence for gastrointestinal infection of SARS-CoV-2. Gastroenterology 158(6):1831-1833. https://doi.org/10.1053/j.gastro.2020.02.055 (e3)

Yadav SK, Chakraborty I, Banerjee S (2020) Bio-medical waste management in India: contemporary approaches and way forward. EPRA Int J Multidiscip Res. https://doi.org/10.36713/epra2013

Yang X, Yu Y, Xu J, Shu H, Xia J, Liu H (2020) Clinical course and outcomes of critically ill patients with SARS-CoV-2 pneumonia in Wuhan, China: a single-centered, retrospective, observational study. Lancet Respir Med. https://doi.org/10.1016/S2213 $-2600(20) 30079-5$
Yu H, Sun X, Solvang WD, Zhao X (2020) Reverse logistics network design for effective management of medical waste in epidemic outbreaks: Insights from the coronavirus disease 2019 (COVID19) outbreak in Wuhan (China). Int J Environ Res Public Health 17(5):1770. doi:https://doi.org/10.3390/ijerph17051770

Yueh MF, Tukey RH (2016) Triclosan: a widespread environmental toxicant with many biological effects. Annu Rev Pharmacol 56:251-272. DOI:https://doi.org/10.1146/annurev-pharmtox010715-103417

Zambrano-Monserrate MA, Ruano MA, Sanchez-Alcalde L (2020) Indirect effects of COVID-19 on the environment. Sci Total Environ. https://doi.org/10.1016/j.scitotenv.2020.138813

Zhou P, Yang X, Wang X (2020a) A pneumonia outbreak associated with a new coronavirus of probable bat origin. Nature 579:270 273. DOI:https://doi.org/10.1038/s41586-020-2012-7

Zhu N, Zhang D, Wang W, Li X, Yang B, Song J (2020) A novel coronavirus from patients with pneumonia in China, 2019. N Engl J Med 382(8):727-733. https://doi.org/10.1056/NEJMoa2001017

Publisher's note Springer Nature remains neutral with regard to jurisdictional claims in published maps and institutional affiliations. 